\title{
Impact Assessment of Hospital-Bound Education Program (HBEP) of the University of Southeastern Philippines -College of Education (USeP - Ced)
}

\author{
Roar A. Callaman \\ Dante O. Calamba \\ Ruby A. Serrano \\ Benjie Q. Badon \\ Maria Lila Y. Chaonui \\ Faculty, College of Education \\ University of Southeastern Philippines \\ Davao City, Philippines
}

\begin{abstract}
This study assessed the impact of Hospital - Bound Educational Program (HBEP) to the lives of children with cancer enrolled in the program. It described how the program provided access to the educational needs of children with cancer. It utilized Qualitative Impact Assessment Protocol (QuIP) to gather evidences of the programs' impact to the beneficiaries. Focus Group Interview and Discussion was conducted among the research participants and thematic analysis was used to analyze the data gathered. The result shows that HBEP provided access to the educational needs of the children with cancer through accommodation and providing appropriate instructional strategies. Moreover, the program sustained the educational needs of children through Multigrade Education and credited instruction under the Department of Education. Finally, the study implies that HBEP contributed significant impact to parents' optimism and sense of purpose, the teachers' renewed commitment in teaching and most especially to the children's positive outlook in life.
\end{abstract}

Keywords: Hospital-bound education program, children with cancer, impact assessment, special education

\section{Rationale}

The "House of Hope" Hospital - Bound Educational Program (HBEP) is one of the extension activities of the College of Education that provides educational access to cancer patients through an Alternative Delivery Mode (ADM) particularly the Modified-In-School-Off-School Approach (MISOSA). HBEP gives children undergoing treatment a chance to keep up with their schooling.

In 2012, the University of Southeastern Philippines (USeP) conducted an evaluation of the feasibility of a hospitalbased school. The university determined that it was entirely possible, with the support from the College of Education (Jalotjot and Gabales, 2013). After a year, the CEd Extension Program was implemented last 2013 in partnership with Southern Philippine Medical Center. In 2017, the program was successfully turned over to the Department of Education - Davao City Division. After six years of implementation, it is timely to assess the impact of the said program for sustainability.

\subsection{Objectives of the Study}

This research study generally aims to document the intended and unintended outcomes to the lives of children with cancer enrolled in the program. Specifically, this study sought to answer the following questions:

1. How was the program able to provide access to the educational needs of children with cancer?

2. In what way was the program able to sustain the educational needs of children with cancer?

3. What are the intended and unintended outcomes of HBEP?

\section{Review of Literature}

The following literatures have been found to have bearing on the present study:

\section{Education for All}

Education for All (EFA) is an international initiative first launched in 1990 to bring the benefits of education to "every citizen in every society." To realize this aim, a broad coalition of national governments, civil society groups, and development agencies such as UNESCO and the World Bank Group committed to achieving six specific education goals: 
- Expand and improve comprehensive early childhood care and education, especially for the most vulnerable and disadvantaged children.

- Ensure that by 2015 all children, particularly girls, those in difficult circumstances, and those belonging to ethnic minorities, have access to and complete, free, and compulsory primary education of good quality.

- Ensure that the learning needs of all young people and adults are met through equitable access to appropriate learning and life-skills programs.

- Achieve a 50\% improvement in adult literacy by 2015, especially for women, and equitable access to basic and continuing education for all adults.

- Eliminate gender disparities in primary and secondary education by 2005 , and achieve gender equality in education by 2015, with a focus on ensuring girls' full and equal access to and achievement in basic education of good quality.

- Improve all aspects of the quality of education and ensure the excellence of all so that recognized and measurable learning outcomes are achieved by all, especially in literacy, numeracy and essential life skills.

\section{Hospital-based schools}

Hospital-bound schools are considered as center for students experiencing problems in health and needing alternative schooling options. An education service offering learning programs for children who are unable to attend or have limited access to an early childhood services because of isolation, illness, a physical disability or itinerancy (Education Counts).

Hospital boundd school at SPMC is guaranteed by Art. 6 Sec. 1.2.8 of Policies and Guidelines in Special Education. Children who are sick and chronically-ill are to be included in the implementation of this fundamental principle. An educational program that is individualized to a specific child, designed to meet that child's unique needs, and from which the child receives educational benefit. School must provide students with an education that emphasizes special education and related services designed to meet their unique needs and prepare them for further education, employment and independent living.

The Davao Children's Cancer Fund Inc. (DCCFI) nonprofit charity organization of advocates for kids with cancer to answer the call of better care and survival for children. Its mission is to bring hope, promote better survival rates and achieve excellent, and holistic care for children with cancer through advocacy, research and environmental protection.

House of Hope $(\mathrm{HOH})$, which is project of RC Waling Waling of Davao and DCCFI is a transient home for children with cancer. It has served about 1000 children and caregivers since its inauguration in August 2007. $\mathrm{HOH}$ decreased treatment abandonment and provided a clean and healing environment for the children afflicted with cancer (Jalotjot and Gabales, 2013).

\section{Children with Special Needs}

Since mid-1960s, both public and private institutions have extended significant support to educational programs catering children with special needs, Gordon \& Browne (2017). In the Philippines, several legislations have been approved to protect and uphold the rights of children to quality education at all level regardless of their growth and developmental pattern.

According to Bee and Boys (2006) as cited by Gordon \& Browne (2017) an estimate of 15 to 20 percent of children in the United States show some form of atypical development and needs special services. Atypical development refers to any deviation on the growth and development pattern of children which may lead to several handicapping situations. Allen and Crowdery (2009) proposed situations which considered children to be exceptional, namely, a child's growth and development is delayed; distorted, atypical, or abnormal; and/or severely or negatively affected.

\section{Theoretical Framework and Conceptual framework}

The study assesses the impact of Hospital-Bound Education Program following the Qualitative Impact Assessment Protocol (QuIP) of Ramnert \& Avard (2016). This gathers evidence of a project's impact through narrative causal statements collected directly from intended project beneficiaries. Participants are asked to talk about the main changes in their lives over a pre-defined recall period and prompted to share what they perceive to be the main drivers of these changes, and to whom or what they attribute any change - which may well be from multiple sources. 


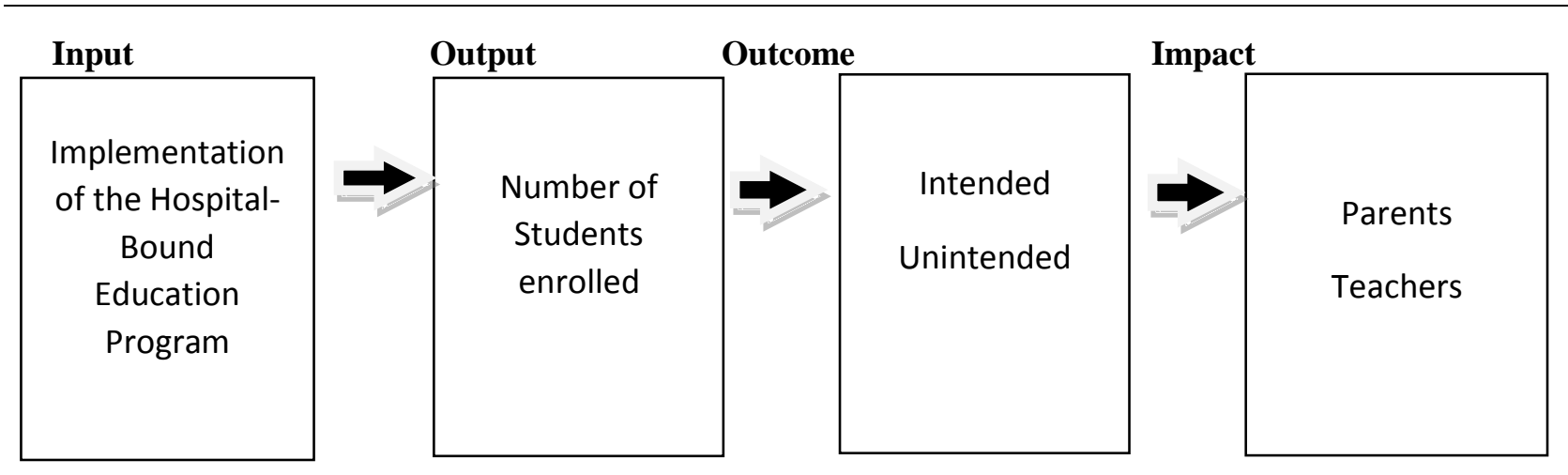

Figure 1. The conceptual framework of the study.

Figure 1 is the conceptual framework of the study. The input would be the implementation of the Hospital-Bound Education Program in the House of Hope. This will serve as a baseline data. The output would be number of students who were enrolled in the program. The outcomes of the study were the evaluative measures of the intended and unintended outcomes. The impact of the study was the changes brought about the program to the parents and teachers.

\section{Methodology}

\subsection{Design}

This study utilized the qualitative impact assessment. This impact evaluation approach draws on contribution analysis. This provides an independent reality check of a predetermined theory of change which helps stakeholders to assess, learn from, and demonstrate the social impact of their work (Remnart \& Avard, 2016). In this approach, the voices of the project beneficiaries are place at the center of the evaluation, enabling them to share and feedback their experiences in an open, credible, and respectful way.

This research design is appropriate because the study aims to gather evidences on the intended and unintended outcomes of the Hospital Bound Education Program.

\subsection{Participants}

The participants of this study were the parents of the children with cancer and the teachers handling these students with cancer.

\subsection{Instrument}

For this study, the researcher-made interview guide questions were utilized in the conduct of Focus Group Interview and Discussion (FGID). Informed consent was secured from the research participants.

\subsection{Data Gathering Procedure}

The following steps were followed in gathering the data to attain the objectives of this study:

Seeking permission from the Schools Division Superintendent. A letter request to conduct the study was secured from the Schools Division Superintendent.

Conduct of the focus group interview and discussion. The researcher conducted the focus group interview and discussion. Proper coordination with the principal, teachers and parents were observed and with reference to ethical standards.

Transcription of the qualitative data. The responses of respondents in the focus group interview and discussion were transcribed to generate patterns for coding and thematic analysis.

\subsection{Data Treatment}

Thematic Analysis was used to analyze the gathered data.This will provide common themes on the intended and unintended outcomes of the program specifically on successful implementation of the program.

\section{Results and Discussions}

\subsection{Access in the educational needs of children with cancer}

\section{Accommodation}

The House of Hope has provided access to the educational needs of the children with cancer. With the current set up of the House of Hope, it paved the way to accommodate the learning needs of the students who are diagnosed and still undergoing treatment. 
Accommodations are generally understood as alterations in the way tasks are presented that allow children with learning disabilities to complete the same assignments as other students. Accommodations do not alter the content of assignments, give students an unfair advantage or in the case of assessments, change what a test measure. They do make it possible for students with LD to show what they know without being impeded by their disability (National Center for Learning Disabilities, 2020).

Accommodation has been clearly expounded by the participants during the focus group discussions. Participants said:

“Angakonganak kay maglisod man ugsulat, so ang answer sapangutanasalibroipatubagsa teacher, orally." [My child had difficulty in writing, so the teacher requires my child to answer the questions orally] (PG1)

"Akonganak kay magsige man nauggawaspag mag klase kayusahaymaghubak mantawon, iconsiderrapudsa teacher. Kung unsaang activities pahabolonra man pudsiya." [My child often gets out of the class specially when he has asthma attack. The teacher was very considerate and allowed him to cope with the classes.] (PG5)

From the statements of the parent-guardians, the students were really accommodated in order for them to have access to their educational needs. National Center for Learning Disabilities (2006) said that once a child has been formally identified with a learning disability, the child or parent may request accommodations for that child's specific needs. The Individuals with Disabilities Education Act states that a child's IEP (Individualized Education Program) team - which both parent and child are a part of — must decide which accommodations are appropriate for him or her. Any appropriate accommodations should be written into a student's IEP. Accommodations may include presentation, response, timing, test scheduling, setting, and others.

As a matter of fact, these statements were confirmed by the teachers assigned in the House of Hope, saying:

"We really recognize and acknowledge their limitations, so we always see to it that we address their needs in every way possible." (T3)

"Lisodsiyapero, kinahanglangyudiconsiderilang situation, or else ma-defeat angpurpose sa program. [IT was hard, but there is a need consider their situation, or else we will defeat the purpose of the program] (T1)

On the other hand, accommodation was also seen when the program opened two shifts - morning and afternoon in order to ensure that the students are given the option to study depending on their available time of the day.

"nag-open mi ogpangbuntagogpanghapon kay nagka-daghannapudsilaunya para makapilisilasailang time para muskwela." [We opened morning and afternoon shifts due to the growing number of students and for them to have the option to choose their schedule.] (T2).

According to IRIS Center Peabody College (2020) identifying and selecting instructional and testing accommodations that will allow the student to access learning is the responsibility of educational program. Before the team can select an accommodation to help a student meet his learning goals, however, they must first identify the barrier affecting his academic performance. In this context the barrier is that students are also undergoing treatments while studying. Addressing this barrier ensures that education and treatment do not conflict with each other.

\section{Appropriateness of Instruction}

At the heart of program effectiveness is the ability to understand the individual profiles - the strengths and weaknesses - of every student in the classroom. The various instructional activities teachers use to engage students with the material and enable them to meet the objectives. Of course, the key is to align instructional strategies with the objectives and assessments.

"Mura man gudsilag normal ngaeskwelahanperodiri mas focus saunsaonpagtudloang among mgaanakngamakalearn." [It appears like the regular school, but the focus here is how to teach our students to ensure learning.] (PG2)

"Dili man nakomadescribeangpagtudlo. Lahirajudsiya. Makaingonkongahaumsiyasa needs saakonganak" [I cannot describe the teaching. It's different. I can say it is appropriate to the needs of my child.] (PG3)

"Kay sa normal school man gud, muragang focus angmgawalaysakit. Kay mao may daghan. Murag ma left out ang limitations sabata. [In a regular school, the focus is on the general population who are healthy. The limitations of the children with cancer may be disregarded.] (PG5)

The teachers also mentioned how they implemented their instructions in such a way that they are appropriate to the needs of the children and the demands of the curriculum standards.

"Mura'ggi-pattern langpudgihaponnamosaUSeP, kay ako grades 5 og6 man ko. Same saUSeP before, nga for this quarter English og Science, next napud Filipino and Social Studies." 
[It's patterned after USeP's instruction before. In my case, since I handle Grades 5 and 6, we teach English and Science for this quarter, then Filipino and Social Studies the next quarter. (T3)

The same participant, justified that their setup is that one that works for the students that they have.

"Kay ing-ani man nga set up mag work sailaha. Lisod kayo if idungantanan subjects." [Set-up like this works for them, because they find it difficult to have all the subjects be included in one quarter.] (T3)

"Another pud, Sir, kay murag tutorial type siya one on one. Focus judsabata." [Another is it is like tutorial type one on one] (T1)

\subsection{Ways sustain the educational needs of children with cancer}

Credited Instruction. The hospital-based education program has sustained the educational needs of the children with cancer to have an education that is credited with Department of Education. Participants mentioned that the program enables them to continue their formal education without going to regular schools and once they decide to go to regular schools, their time and effort will be credited.

"Kung mahumannasiladirisasulod, pwedena man ipadayonnalangsa regular school." [Once they are done here in House of Hope, they can continue their education in regular schools]

"Dili masayangang effort kay irecord man siya as Grade 2 diri. Kung mahumansiyadiri, Grade 3 nasilasunod." [The effort is not wasted because she is enrolled as Grade 2 here. If she finishes Grade 2 here, she will move up to Grade 3 next year].

"Actually, enrolled man judsilasaDepED, so dilisiya pressure nga experience, pero credited siya." [They are actually enrolled with DepED. The experience is not full of pressures, but it is credited.]

\section{Multigrade Education}

The hospital-based education program is multigrade which sustained the educational needs of the children with cancer. Multigrade education ensures that there will be teachers available to cater the different curricula. Participants explained that this kind of set-up is flexible and the teachers were able to teach more students compared to monograde teaching.

"Maayoangdagansaprograma kay naagyuymgamagtutudlosa lain-laing curriculum. Siguradogyudngamatudluanangtanan." [The program is great because there are teachers in different curricula. For sure, everyone will be catered].

"Dili makulanganugmagtutudlosa House of Hope kay kadausakamagtutudlomaggunit man ugduha ka curriculum. Usahay, angusakamagtutudlomaggunitsa grade 5 ug grade 6." [There will be no lack of teachers in the House of Hope because each teacher handles two curricula. Sometimes, one teacher will handle grade 5 and grade 6.]

"Daghangyudugmatudluanangmgamagtutudlosainganingasistema kay bisanunsanga grade level matudluan man nila. Dili napudkinahanglanngadaghanugmagtutudlokada grade level kay kaya ramanpudsapipila." [This kind of scheme will aid the teachers to teach more students even in different grade levels. There is no need to have many teachers in every grade level because few teachers will do].

\subsection{The intended and unintended outcomes of HBEP}

\subsubsection{Intended Outcomes}

\section{Address Educational Needs}

The hospital-based education program has brought countless intended outcomes. One of these is it address educational needs. Education is a fundamental human right and essential for all other human rights. It is a powerful tool by which socially and economically marginalized children and adults can lift themselves out of poverty. It also consists of the right to freedom of education. Freedom of education is the right given to human beings to have access to the education of their preference without any constrictions. Children in the House of Hope and other hospitals deserve to cater their educational needs. Participants expressed their gratitude for opening new doors to their children and giving them the opportunities to learn despite their struggles.

"Ang House of Hope naghatagugopurtunidadnamakatuonangmgabatabisannaasiladirisaospital." [The House of Hope gives opportunity to children to learn despite that they are in the hospital.]

“Nalipaykonganagpadayongihaponangpagtuonsaakoanganakdirisa House of Hope." [I am happy that my son continues his study in the House of Hope.]

"Kinahanglangyudsamgabatangaipadayongihaponnilailahangpag-eskwela." [The children need to continue their studies because it is important.] 


\section{Development of Cognitive Skills}

Another intended outcome of the program is the development of cognitive skills. Cognitive skills include the ability to learn, to process and apply knowledge, to analyze and reason, and to evaluate and decide (Doyle, 2019). Many studies over many decades have shown that cognitive skills are a determining factor of an individual's learning ability. According to Oxfordlearning.com it is the skills that "separate the good learners from the so-so learners." In principle, when cognitive skills are strong, learning is fast and easy. When cognitive skills are weak, learning becomes a challenge.

For the past years, teachers, parents, and those who are involved in the House of Hope observe that there is a significant development of cognitive skills of children. Through the hospital-based education program and the unending efforts of the teachers, the education of children continues and their learning ability advances. Parents are very happy every time they see their children improves every day.

"Nalipayko kay Nakitanakonganaga-improve angakoanganaksaiyangpagtuon." [I am happy to see my daughter improves in her study.]

"Wala nakogiexpectnga mas maalamonnaakoanganakdirisa House of Hope. Sa una, maglisodsiyagsulbadsamgaproblemanganaasalibro, karun, nihawdnasiya." [ I didn't expect that my son is more intelligent in the House of Hope. Before, he had difficulty in solving problems in the book, now, he is doing better.]

\section{Psychosocial well-being}

In addition to address educational needs and develop cognitive skills, psychosocial well-being is also an intended outcome of hospital-based education program. The phrase "psychosocial well-being" is used to describe an individual's emotional health and overall functioning. The author of a study published in Applied Psychology: Health and Well-Being describes psychosocial well-being as "the combination of feeling good and functioning effectively." Researchers also have found that the absence of distress doesn't necessarily indicate a person has high psychological well-being. High psychological well-being is about feeling happy and doing well. People with high psychosocial well-being report feeling capable, happy, well-supported, and satisfied with life (Morin, 2020).

Children in the House of Hope show an improve psychosocial well-being. They haveinter- and intra-individual levels of positive functioning that can include one's relatedness with others and self-referent attitudes that include one's sense of mastery and personal growth.

"Naobservednamona mas niayoang well-being samgabatadililang physically patipud mentally ug socially." [We observed that the well-being of the children improves not just physically but also mentally and socially.]

\subsubsection{Unintended Outcomes}

Stronger Bond between Child and Parents. The hospital-based education program has also brought innumerable unintended outcomes. One of these is stronger bond between child and parents. House of Hope is a home for camaraderie and parent-child relationship is foster. As time goes by, the child and parents will spend more time to each other nurturing the physical, emotional, and social development of the child. The relationship lays the foundation for the child's personality, choices, and overall behavior. Studies suggest that a healthy parent-child relationship leads to positive outcomes for the children and the family (Moore, et.al., 2011).

Parents believe that the program enables them to spend more time to their child, to know their talents and capabilities, and teach them lessons. The program is indeed paved the way to stronger bond between child and parents.

"Maayo kayo akoangrelasyonsaakoanganaklabinakarunnganaakopirmisaiyangkilid." [My relationship to my child is better especially now that I am always on his side.]

"Napansinnakonga mas niclose mi saakoanganak." [I noticed that me and my child is closer to each other.]

"Mas nahatagannakoakoanganakugatensyondirisa House of Hope." [I gave more attention to my child in the House of Hope.]

\section{Optimism of Parents}

An additional to unintended outcome is the optimism of parents. Optimism can be defined as a feeling that good things will happen and that something will be successful or more specifically as extent to which people hold generalized favorable expectancies for their future. It's a characteristic trait which is unique and observed in certain individuals. It's a form of mental state in which, one believes that the outcome of some specific task or result, will be positive or good. 
Participants stated that they are looking forward to overcome their struggles. They believe that the children in the House of Hope will be healed and win the battle.

The House of Hope envisions to bring hope, promote better survival rates and achieve excellent, holistic care for children with cancer through advocacy, research, and environmental protection. The hospital-based education program boosts the optimism of parents.

"Nituokongamakalampos rami saamoangginasagubangkarunugmahimomingmadaugonlabansa cancer." [I believe that we will overcome the struggles we are facing today and we will emerge as victorious in our battle against cancer.]

"Makauli rami diripuhonngahimsog, malipayon, ug cancer free." [We will go home healthy, happy, and cancer free.]

"Nakatabanggyudsaamoaang hospital-based education program kay nagahatagkanamougpositibongapanan-aw sakinabuhi." [The hospital-based education program helped us to have a positive outlook in life.]

\section{Motivation of Learners}

Another unintended outcome is motivation of learners. Motivation is the word derived from the word 'motive' which means needs, desires, wants or drives within the individuals. It is the process of stimulating people to actions to accomplish the goals. Reeve (2015) explains that whether we define motivation as a drive or a need, it is a condition inside us that desires a change, either in the self or the environment. When we tap into this well of energy, motivation endows the person with the drive and direction needed to engage with the environment in an adaptive, open-ended, and problem-solving sort of way.

The students of the hospital-based education program are perceived to be motivated to learn. They are willing to learn a lot from their teachers and do the tasks given to them. They are also motivated to do creative things such as writing, drawing, and painting. Generally speaking, they are motivated in life. Participants cited that their child are inspired to learn and glad with the teachers.

"Gusto gyud kayo sakonganaknamakatuonhabangnaasiyadariasa hospital." [My child really wants to learn while she's here in the hospital.]

"Makita nakosaakoanganaknadeterminadosiyamakatuonugmalipaysiyapagtingklase." [I can see the determination of my child to learn and he's happy every time there's a class.]

“Malipayakoanganakpagmuabotnailangmaestra kay malingawsiyapagmagklasena." [My child is happy every time their teacher arrives because she enjoys the class.]

\subsection{Impact of Hospital-Bound Education Program}

\subsubsection{Parents}

Parents are the persons who have seen the important impact of the Hospital-Bound Education Program. Their experiences have shaped their views and ways in life. For one, they said that they have developed Optimism.

"Life goes on. I look at the positive aspects of life. Kung down ko[If I feel down], I recall the fact that a lot of people work hand in hand to help us sa among sitwasyon [in our situation], just like the HBEP" (P2)

"During the early part of the chemotherapy I muranakougmusurrender [felt like giving up]. But this experience has taught me to focus on what is good ugdilimagpadalasapagsulay [and not give in to trials]." (P3)

Sense of Purpose is one of the impacts that parents can take from the program. They shared that as parents having a child suffering from cancer did not rob them of the hope that they have. Instead, it has clarified their sense of purpose.

"Dili langdiay among purpose kay magpatambalsa among anak. Kundinaapa mi masimportantenga purpose nga to be by our children satanannilangapagsulay. Saakoalang, it redefined the concept of parenting." [The purpose was not just to seek medical attention for our children, but more importantly was to be by their side in these trials. For me, it redefined the concept of parenting.](P4)

"Ako as a parent, usahaymakapangutanakounsajuddiayang role nako? Dili man typical ang role og purpose namo as parents with cancer patients namgaanak. Kininakahatagsaakoasa realization ngaangtinuodnga purpose sapagkaginikanandiliangpag provide samga material things. Isa gyudka purpose saginikananngaununganangmgaanakmaskiunsa pa."[As a parent, I sometimes asked what really my role is. Our roles and purpose as parents of cancer patients is not a typical one. It gave me a realization that the true purpose of being parents is not just to be able to provide material things. One purpose is to stay by the side of our children no matter what.] 


\subsubsection{Teachers}

The Hospital-Bound Education Program has brought a lot of changes in the lives of teachers. One of the impacts identified by the teachers was Renewed Commitment. Teachers said that the experience they had in the House of Hope is one of a kind. One teacher said:

"Every time I go to work; I bear in mind that I have to do everything to make these learners learn." (T1)

"There was a point before when I almost lost the passion for teaching, but the experience has made me revive that commitment". (T2)

Changed perspective was also seen among teachers. They said that they consider their experience a source of inspiration and a source of positive outlook.

"We are here in House of Hope to teach, but it is us who are in fact learning a lot - about life, about views in life. I consider it a source of inspiration to be with the students every day." (T2)

\section{Implications}

The foremost implication of this study lies on educational programming. Classroom accommodation is critical for the success of hospital-based educational program. There is a need to continue and even improve the program to enable wider reach to potential learners with limitations, such as cancer. Because Hospital-based educational program provides therapeutic and normalcy opportunities to children with cancer, its educational program can be a favorable option for continued education among children with cancer. A framework on the provision of hospitalbased instruction can improve practices.

\section{References}

Doyle, A. (2019). Cognitive Skills: Employers Look for in an Employee. Retrieved on August 15, 2020 from https://www.thebalancecareers.com/cognitive-skills-definition-and-example

Education for All. Retrieved from https://www.worldbank.org/en/topic/education/brief/education-for-all

Gordon, Ann Miles and Browne, Kathryn Williams (2011). "Beginnings and Beyond:Foundations in Early Childhood Education, Eighth Edition", Cengage Learning, Wadsworth 20 Davis Drive Belmont, USA

IRIS Center Peabody College (2020). Selecting an Accommodation. Retrieved November 20, 2020 from https://iris.peabody.vanderbilt.edu/module/acc/cresource/q2/p04/

Jalotjot, E and Gabales, B., Jr. (2013). Establishing a hospital-based school: aProactiveevaluation. Paper presented during the $4^{\text {th }}$ International Conferencein SpecialEducation: ASEAN perspectives at graduate School SuanDusitRajabhatUniversity, Bangkok.

Moore, K., Kinghorn, A., \& Bandy, T. (2011). Parental Relationship Quality and Child Outcomes Across Subgroups. Child Trends Research Brief, 2011-13.

Morin, A. (2020). How to Improve Your Psychological Well-Being: Your emotional health is key to a happy life. Retrieved on August 15, 2020 from https://www.verywellmind.com/improve-psychological-well-being4177330.

National Center for Learning Disabilities (2006). Accommodations for Students with LD. Retrieved November 20, 2020 fromhttp://www.ldonline.org/article/8022/

Reeve, J. (2015). Understanding motivation and emotion (6th ed.). Hoboken, NJ:Wiley.

Remnant, F. and Avard, R. (2016). Qualitative Impact Assessment Protocol.(QUIP) Better Evaluation. Retrieved from http://betterevaluation.org/approach/QUIPRetrieved from http://www.educationcounts.govt.nz/dataservices/glossary. 